\section{Facile synthesis and biological evaluation of chrysin derivatives}

\author{
Nicholas Omonga', Zakia Zia ${ }^{2}$, Hesham Ghanbour', \\ Abby Ragazzon-Smith ${ }^{3}$, Howard Foster', John Hadfield' \\ and Patricia Ragazzon ${ }^{4}$ (D)
}

Journal of Chemical Research $1-10$

(C) The Author(s) 2021

Article reuse guidelines: sagepub.com/journals-permissions DOI: $10.1177 / 17475198211057467$ journals.sagepub.com/home/ch

(SAGE

\begin{abstract}
In this paper, novel synthetic methods, including microwave $O$-alkylation, were used to produce several chrysin derivatives. These compounds were purified, characterised and tested on different cell lines and bacterial strains. From this family, 7-(2,4-dinitrophenoxy)-5-hydroxy-3-phenyl-4H-chromen-4-one (C3) was shown to be extremely active on bacterial strains methicillin-resistant Staphylococcus aureus, Pseudomonas aeruginosa and Klebsiella pneumoniae as well as having anticancer activity on a range of cancer cell lines with $\mathrm{IC}_{50}$ values less than $30 \mu \mathrm{M}$. Chrysin has been known for their anticancer and antimicrobial properties, and this study not only corroborates this but also shows that it is possible to synthesise new improved derivatives with therapeutic possibilities.
\end{abstract}

\title{
Keywords
}

antibacterial, antifungal, chrysin derivatives, cytotoxicity, microwave

Date received: 3 September 2021; accepted: 18 October 202 I

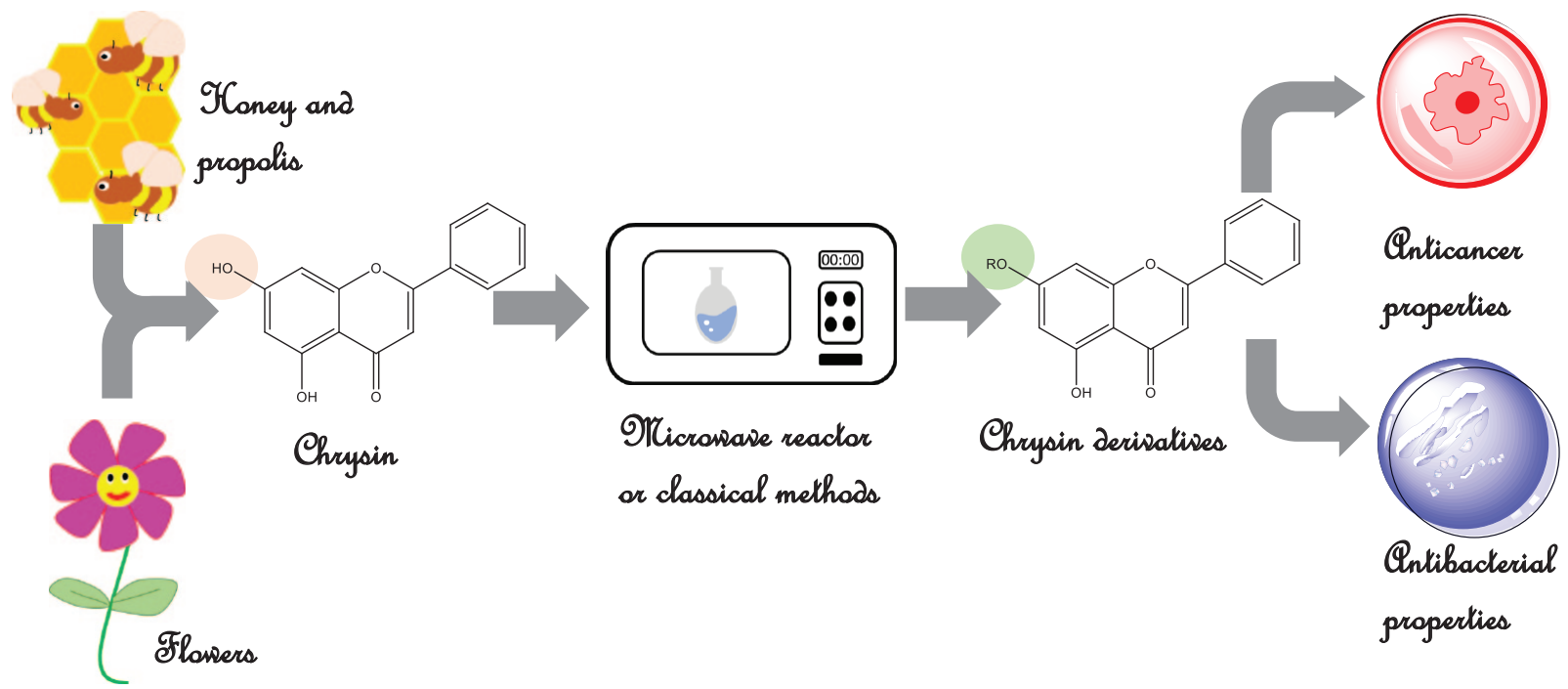

\section{Introduction}

In the search for new drugs to overcome drug-resistant infections and cancers, phytochemicals have become the go-to source for inspiration. In plants, isoprenoids serve as the backbone from which many phytochemicals are biosynthesised via the cytosolic mevalonate (MVA) and the 2C-methyl- $D$-erythritol-4-phosphate (MEP) pathways. ${ }^{1}$ Some phytochemicals, like flavonoids, are synthesised via the phenylpropanoid pathway, they exhibit both
'Biomedical Research Centre, School of Science, Engineering and Environment, University of Salford, Salford, UK

${ }^{2}$ Labcorp Clinical Research Unit Limited, Leeds, UK

${ }^{3}$ School of Science and the Environment, Manchester Metropolitan University, Manchester, UK

${ }^{4}$ School of Pharmacy and Bioengineering, Keele University, Keele, UK

Corresponding author:

Patricia Ragazzon, Hornbeam 2.26, School of Pharmacy and

Bioengineering, Keele, University, Keele, Staffordshire, ST5 \%BG, UK.

Email: p.ragazzon@keele.ac.uk 
antimicrobial and anticancer activities. ${ }^{2}$ The antimicrobial activity could be a result of impairment of the cell membrane integrity and cell agglutination. ${ }^{3}$ The anticancer activity could be due to modulation of various mechanisms such as angiogenesis, apoptosis, metastasis, differentiation and cell proliferation., ${ }^{4,5}$ The increase in research targeted at developing new drugs for cancer and infectious diseases has gained momentum in the last decades.

Chrysin is a flavonoid predominantly present found in honey, blue passionflower and propolis. ${ }^{6}$ In vitro studies on chrysin and chrysin derivatives have demonstrated interesting biological activity. ${ }^{7}$ Chrysin has shown potential anticancer activities on several cancer cell lines including those derived from cancers of the prostate, pancreas, thyroid, glioblastoma, liver, cervical, nasopharyngeal, breast, lungs and haematological cancers. ${ }^{6,8}$ The mode of action of chrysin has been shown to be via apoptosis, cell proliferation and removal of inflammatory responses, suppression of NF-KB and angiogenesis. ${ }^{9-11}$ Antibacterial activity of flavonoids, including chrysin, has been reported against Grampositive and Gram-negative bacteria. ${ }^{12-16}$

7-O-Alkylchrysin derivatives have been explored for anticancer activity. ${ }^{17}$ Our group has extensive expertise in synthesising different flavonoid derivatives. ${ }^{18-20}$ In this paper, we explored the effect on the biological activity of different functional groups added on the position 7 in chrysin. To compare different moieties and carbon length chains, we synthesised both known and novel chrysin derivatives. 7-O-Bromochrysin and 7-O-alkylchrysin derivatives were explored employing green microwave processes in majority of the cases. The aim of this study was to investigate the antibacterial and anticancer activity of a group of chrysin derivatives with a range of different substituents.

\section{Results and discussions}

\section{Chemistry}

Chrysin (shown in Figure 1) was used as the core flavone structure, modifications were undertaken at the 7-hydroxyl group using different methods. Different reaction solvents such as acetone, acetonitrile, dimethylformamide as well as different equivalents were used for addition of the linkers. Potassium carbonate $\left(\mathrm{K}_{2} \mathrm{CO}_{3}\right)$ has been widely used in $\mathrm{O}$-alkylation synthetic methods as a base reagent with the intention of producing a phenoxide anion on the chrysin scaffold. ${ }^{21}$ This nucleophile will then react with the electrophilic R groups (Br-alkyl groups). Different equivalents were used with some reactions favouring 2 equiv. or 4 equiv. to chrysin. Microwave chemistry has been at the front of green chemistry synthetic methods as it allows for reduction of solvent used, time and electricity as well as making some reactions more favourable. ${ }^{18} \mathrm{O}$-alkylation in chrysin is favoured on position 7 , this is due to the interaction between the carbonyl oxygen in position 4 and the hydroxyl in position $5 .{ }^{19}$ The proximity of these two groups allows the formation of hydrogen bonding which requires harsher conditions for $O$-alkylation. Steric hindrance also

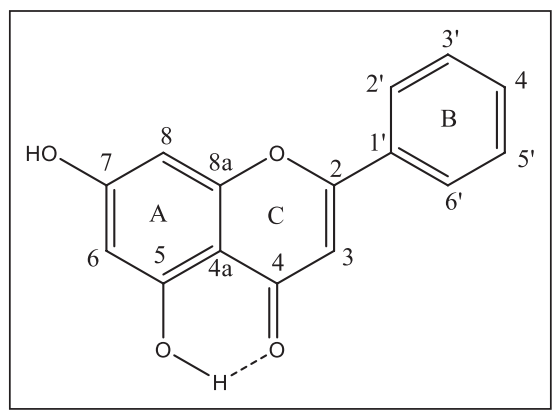

Figure I. Chrysin, showing the traditional numbering of positions.

plays an important role, while the hydroxyl in position 7 is free to interact with bulky groups, only small groups would be possible to interact with the hydroxyl in position $5 .^{22-24}$

We have explored all these conditions and synthetised a range of chrysin derivatives using stirring or microwave techniques, selecting the ones that presented the highest yields. Compounds $\mathbf{C 1}-\mathbf{C 3}$ and $\mathbf{C 5}-\mathbf{C 7}$ were synthesised through application of microwave-assisted $\mathrm{O}$-alkylation in either acetone (method A) or acetonitrile (method C) (Scheme 1). Compounds C4 and C8 were synthesised through classical stirring $O$-alkylation as the microwave approach produced extremely low yields. The Mitsunobu reaction was also explored, using different conditions including sonication. ${ }^{25}$ However, these gave lower yields and purification problems. The use of a microwave reactor and less-hazardous reactants were aligned to a greener chemistry approach which was beneficial for most of our compounds as it reduced the reaction time from $12-24 \mathrm{~h}$ to just $0.2 \mathrm{~h}$ with a yield $>45 \%$. The microwave reactions were undertaken in $35-\mathrm{mL}$ Pyrex pressure vessels, sealed with SP-D Pressure Caps both from CEM UK to which the reactants were added and suspended in a minimal volume. In the case of $\mathrm{C} 4$, tetra- $n$-butylammonium bromide was brought into the reaction, and this phase transfer catalyst has been widely used in single-phase microwave reactions to improve product yields by increasing the accessibility of the reagents to the liquid phase, in this dimethylformamide. ${ }^{26}$ Scheme 1 indicates the chrysin structure and the substituents employed for the $O$-alkylation.

7-O-alkylchrysin derivatives C1, C2, C4, C6, C7 and C8 were novel compounds. While C3 has been recently available commercially (Akos GmbH, Germany. SigmaAldrich, UK. Mcule, USA), this compound has not been made available through the database Reaxys, so we present here its first characterisation.

Introduction of alkyl chains has the potential to form more lipophilic compounds, which could enhance the entrance of the compound into cells. This was explored for both carbon alkyl chains as well as halogen species opening up the possibility to form additional targets on further reaction. ${ }^{27}$ Compound $\mathbf{3}$ has two nitro groups; nitro moieties have been a classic presence in drug design. ${ }^{28}$

A total of eight chrysin derivatives were synthesised and characterised. The structures of the products were confirmed 


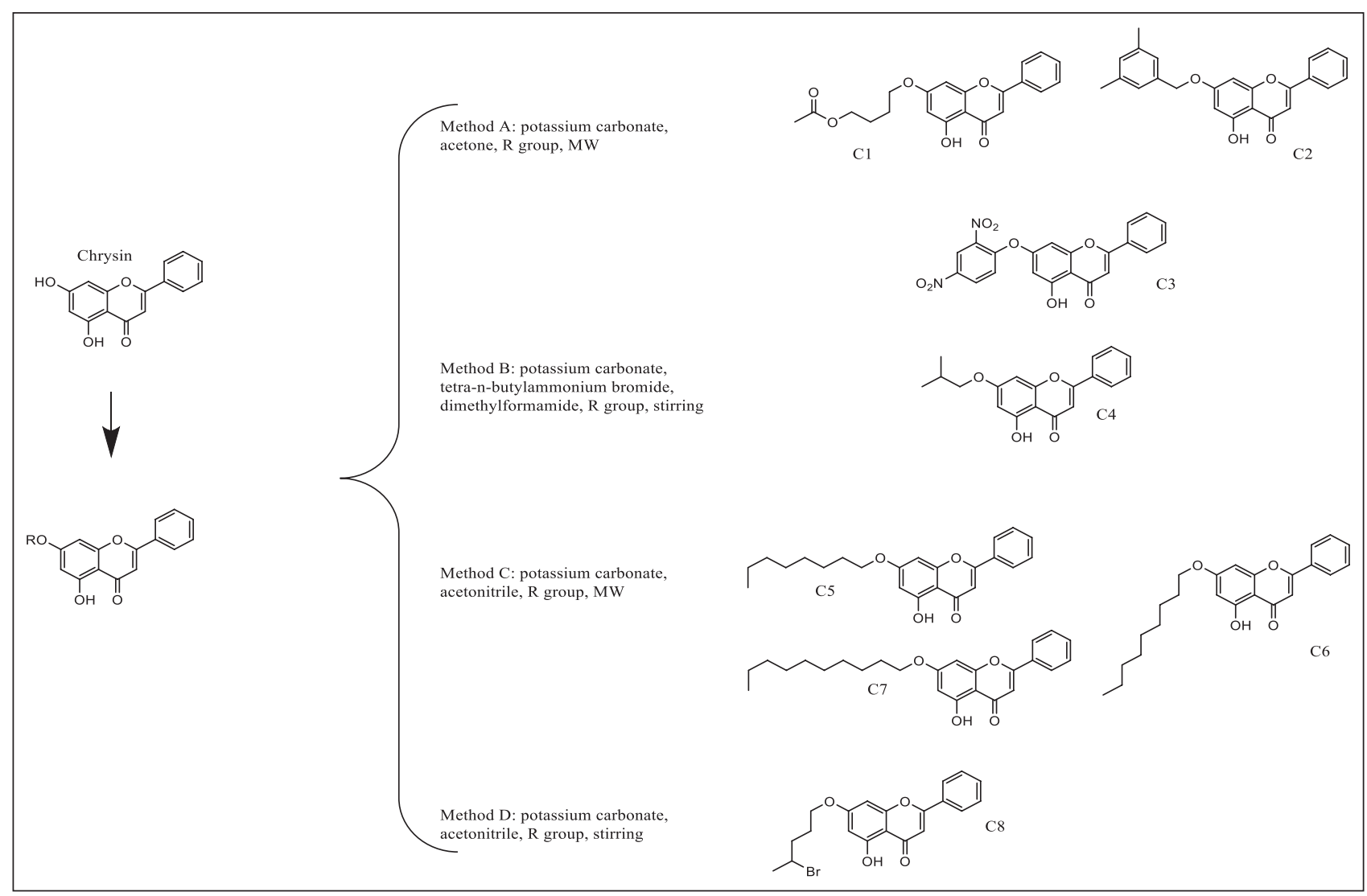

Scheme I. General method for the synthesis of chrysin derivatives. Common numbering of protons on flavonoids is shown on chrysin structure. Carbon chains are numbered in the supplementary material. Yields presented in \%: CI (80), C2 (52), C3 (46), C4 (75), C5 (49), C6 (47), C7 (56) and C8 (94).

by ${ }^{1} \mathrm{H}$ NMR, ${ }^{13} \mathrm{C}$ NMR, IR and Mass Spectral data. All the compounds were taken for biological studies.

\section{Antibacterial activity}

In this study, we investigated the activity of the new derivatives on Gram-negative bacteria (Escherichia coli, Pseudomonas aeruginosa, Pseudomonas fluorescens and Klebsiella pneumoniae) and Gram-positive bacteria (Staphylococcus aureus and Enterococcus). E. coli dwell mainly in the intestine of humans and animals; the pathogenic strains can cause bloody diarrhoea ${ }^{23}$ vomiting and severe abdominal cramp. It is one of the major causes of food poisoning. ${ }^{29,30}$ The extended-spectrum $\beta$-lactamase (ESBL)-producing E. coli are of major importance due to their antibiotic resistance. ESBL are enzymes that confer antimicrobial resistance to most $\beta$-lactam antibiotics such as the monobactam aztreonam, cephalosporins and penicillins. ${ }^{31}$ P. aeruginosa causes ventilator-associated pneumonia and other nosocomial infections as well as sepsis syndrome. ${ }^{32,33}$ Recently, the World Health Organization (WHO) has identified $P$. aeruginosa as a priority pathogen due to the threat of extremely drug-resistant infections. ${ }^{34} P$. fluorescens is rarely a cause of human disease; however, it might affect patients with a compromised immune system caused by cancer, cases have been reported of contaminated blood given through transfusions. ${ }^{35}$ This strain also produces antibiotics like mupirocin which are used in creams to treat skin MRSA-active infections. ${ }^{36} \mathrm{~K}$. pneumoniae is present in the intestine, skin and mouth as a normal flora of these tissues, and it can damage the lungs (alveoli) if inhaled. They are resistant to most drugs, ${ }^{37}$ and it is the third microorganism commonly isolated in blood cultures of patients with sepsis. ${ }^{38}$ S. aureus is found on the skin, respiratory tract and nose, and is responsible for food poisoning, abscess, skin and soft tissue infections, wound and respiratory infections. It is also responsible for toxic shock syndrome, cellulitis, impetigo and boils. ${ }^{39,40}$ The introduction of penicillin reduced the high mortality but led to the development of $\beta$-lactamases which destroy penicillin. A semisynthetic penicillin analogue - methicillin was introduced; however, S. aureus resistant to methicillin emerged rapidly (MRSA).$^{41}$ Enterococcus is associated with nosocomial infections as it rapidly acquires antibacterial resistance. ${ }^{42}$ The Candida albicans fungus is a lifelong, harmless commensal member of the normal human microbiome. However, C. albicans can cause infections that range from superficial infections of the skin to life-threatening systemic infections under certain circumstances. ${ }^{43}$ Several activities and factors have been identified which contributes to the pathogenic nature of this fungus. This includes biofilm formation, secretion of hydrolases, molecules which mediate invasion and adhesion to the host cells, phenotypic switching and thigmotropism. ${ }^{43}$ C. albicans can cause two major infections in humans: superficial infections and oral candidiasis and life-threatening systemic 
Table I. Effect of chrysin derivatives on Escherichia coli, Pseudomonas aeruginosa, Klebsiella, Staphylococcus aureus, Enterococcus and Bacillus cereus following $72 \mathrm{~h}$ of drug treatment MIC is recorded in $\mu \mathrm{g} \mathrm{mL} \mathrm{L}^{-1}$.

\begin{tabular}{|c|c|c|c|c|c|c|c|c|}
\hline \multirow[t]{2}{*}{ Compounds } & \multicolumn{8}{|c|}{$\mathrm{MIC}$ in $\mu g \mathrm{~mL}^{-I^{*}}$} \\
\hline & E. coli & P. aeruginosa & S. aureus & MRSA 252 & E. faecalis & P. fluorescens & K. pneumonia & C. albicans \\
\hline Cl & 50 & 100 & 25 & 100 & 50 & 62.5 & 125 & 50 \\
\hline $\mathrm{C} 2$ & 100 & 200 & 50 & 250 & 100 & 125 & 250 & 400 \\
\hline C3 & 12.5 & 25 & 12.5 & 62.5 & 12.5 & 31.3 & 62.5 & 50 \\
\hline C4 & 100 & 200 & 100 & - & - & 125 & 250 & 100 \\
\hline C5-C7 & - & - & - & - & - & - & - & - \\
\hline C8 & 100 & - & 50 & 125 & 100 & - & - & 200 \\
\hline Chr & 250 & - & 125 & - & 250 & 500 & - & 200 \\
\hline G & 8 & 16 & 8 & 32 & 8 & 16 & 16 & \\
\hline $\mathbf{F}$ & & & & & & & & 125 \\
\hline
\end{tabular}

MIC: Minimum Inhibitory Concentration; Chr: chrysin; G: gentamicin, this aminoglycoside has a wide range of antibacterial activity making it ideal as a positive control on activity tests; ${ }^{44,45} \mathrm{~F}$ : fluconazole, this antifungal agent is widely used to treat $C$. albicans infection presenting a variable range of MIC. ${ }^{46}$

No observed inhibition at MIC values $\leqslant 250 \mu \mathrm{g} \mathrm{mL}-1$.

$*$ MIC values are expressed as a mean value \pm SD from two independent experiments performed in triplicate.

infections which could spread into vital organs. ${ }^{44}$ C. albicans (up to $75 \%$ ) is present in the oral cavity and remains benign in normal humans but could cause recalcitrant oral cavity infection in immunocompromised individuals. ${ }^{43}$

Minimum Inhibitory Concentration (MIC) is defined as the lowest concentration of an ingredient that prevents visible growth of bacteria, used to evaluate the antimicrobial efficacy of compounds. As shown in Table 1, chrysin showed very weak antibacterial activity on the tested strains. This is in agreement with different studies, in where several flavonoids including chrysin, have shown modest studies. ${ }^{44} \mathbf{C 5}$ and $\mathbf{C 6}$ did not demonstrate any antibacterial activity on the tested strains. C2 and C8 showed weak activity on the strains, although they presented some selectivity for $S$. aureus. C4 was very weak antibacterial agents with either very low or no activity. Only $\mathbf{C 1}$ and $\mathbf{C 3}$ showed activity on our tests. C1, although active on all the strains, clearly showed selectivity for S. aureus; while C3 was the most active one with activities closer to the ones demonstrated by the positive control on all the strains, specially on Gram-negative E. coli, and Grampositive $S$. aureus and Enterococcus faecalis. C1 and C3 had the most polar groups in our family, with a carbonyl group (C1) and two nitro groups (C3), adding localised charges to the molecules. In respect to the parent compound, C3 showed a 20-fold increase of activity on E. coli and E. faecalis, 16-fold increase on P. fluorescens and 10-fold increase in activity on $S$. aureus; while C1 achieved half of C3's activity. Although the functional group $\mathrm{NO}_{2}$ has been indicated in many cases as toxic or prone to toxicity, several antibacterial and antifungal agents containing $\mathrm{NO}_{2}$ are currently available commercially or in late phase of clinical trial, some examples include oxamniquine, nimorazole, OPC-67683 and fexinidazole. ${ }^{45}$ While chrysin was not active on $P$. aeruginosa, MRSA and $K$. pneumoniae, compounds C1 and C3 showed activity on these strains. It is interesting that the novel compound $\mathbf{3}$ was active on the number of strains especially difficult to treat strains such as MRSA, P. aeruginosa and $K$. pneumoniae.
Li et al. ${ }^{46}$ had previously synthesised chrysin derivatives containing 3-carbon spacers attached to different positions. Their results on $7-\mathrm{OH}$ derivatives showed they were the most effective with MIC values ranging from 3.13 to $50 \mu \mathrm{g} \mathrm{mL}^{-1}$ against $S$. aureus and E. coli, respectively. Another study using piperazine chrysin derivatives showed $\mathrm{IC}_{50} \mu \mathrm{g} \mathrm{mL}^{-1}$ values in the range of 1.30 to 4 for $S$. aureus, 1.15 to 7 for E. Coli and 10 to $>50$ for $P$. aeruginosa. ${ }^{47}$ Only a handful of studies include chrysin or chrysin derivatives include investigation on $M R S A$, Alhadrami et al. $^{48}$ reported MIC values of 15 and $250 \mu \mathrm{g} \mathrm{mL}^{-1}$ for chrysin and hesperidin, a chrysin derivative, respectively. Similarly to the $M R S A$, flavonoids including chrysin have not been extensively studied on $P$. fluorescens; some reports related more to the food industry and packaging have reported propolis presenting antibacterial effect for $P$. aeruginosa and $P$. fluorensces. ${ }^{49} \mathrm{Zhu}$ et al. ${ }^{50}$ reported the synthesis of several chrysin derivatives with antimicrobial activity; results of MIC were in the range of $50 \mu \mathrm{g} \mathrm{mL}^{-1}$ for $K$. pneumoniae and $3 \mathrm{mg} \mathrm{mL}^{-1}$ for C. albicans.

C1 and C3 demonstrated a potentially useful antifungal activity with MIC value range of $50 \mu \mathrm{g} \mathrm{mL}^{-1}$. These findings are in agreement with our results. $\mathbf{C 5}$ and $\mathbf{C 6}$ did not present any antimicrobial activity.

\section{Anticancer activity}

The growth inhibition activities of this family of chrysin derivatives were determined in a series of tumour and nontumour cell lines. These cell lines represent some of the most common cancer types including leukaemia (myeloid K562 and lymphoid MOLT-4), colorectal (HCT-116 and Caco-2), breast (MCF-7 and MDA-MB 468), hepatocellular cancer (HepG2), lung cancer (A549), malignant mesothelioma (Mero-14), along with an immortalised normal bronchial epithelium cell line (BEAS-2B). BEAS-2B was used as a control to determine if the growth inhibition activity was specific to cancerous cell lines, an ideal anticancer agent would not be active on non-cancerous cells. 
The results are shown in Table 2. Chrysin was very active in our studies with $\mathrm{IC}_{50}$ values ranging from 3 to $50 \mu \mathrm{M}$, including the non-cancerous cell line BEAS-2B. On colorectal cancer model HCT-116, all compounds were relatively active, especially $\mathbf{C 1}, \mathbf{C 2}$ and $\mathbf{C 3}$ with similar activities on Caco-2, another colorectal cancer model. On breast cancer models MCF-7 and MDA-MB468, only C1, C2 and C3 showed activity; although chrysin, the parent compound, showed to be more active than its derivatives. On the hepatic cell line HepG2, majority of the compounds showed no activity although $\mathbf{C 1}, \mathbf{C} 3$ and $\mathbf{C 8}$ showed activity while chrysin was more active than them. MOLT- 4 and K562 are models for potential antileukaemia activity. Chrysin showed the lowest $\mathrm{IC}_{50}$ values on these two cell lines and was therefore the most active flavonoid, although C1, C3 and C8 showed activity as well. C1, C2 and C3 had similar ranges of activity to chrysin on K562. A549 is a relevant model of lung cancer and Mero-14 has been employed as model for malignant mesothelioma especially in relation to asbestos. ${ }^{51,54}$ Chrysin was active on these two cell lines, with more affinity on A549 than Mero-14; in the case of A549, C8 demonstrated a reasonable activity while C1 and C3 were slightly weaker. On Mero-14, chrysin was not very active but $\mathbf{C 1}, \mathbf{C} 3$ and $\mathbf{C 8}$ showed activities with $\mathrm{IC}_{50}$ lower than $10 \mu \mathrm{M}$. BEAS-2B is a cell line derived from normal bronchial epithelia extracted during the autopsy of non-cancerous individuals. ${ }^{52,55} \mathrm{BEAS}-2 \mathrm{~B}$ can be used up to a certain degree to assess if a compound active on cancer cells is toxic to non-cancerous cells. Chrysin and $\mathbf{C 2}$ were moderately toxic with an $\mathrm{IC}_{50} \sim 50 \mu \mathrm{M}$, all the remaining compounds were either non-toxic on the cells or with low activity.

The results showed that chrysin was an active compound, but it is also toxic to non-cancerous cells. From the derivatives, $\mathbf{C} \mathbf{1}$ and $\mathbf{C} \mathbf{3}$ were the most active across the spectrum of cell lines with weak activities on non-cancerous cells. C5 and C6 showed preference for colon carcinomas. C5, C6 and C8 showed more selectivity for breast cancer model MDA-MB468 with C8 also showing activity on malignant mesothelioma Mero-14.

Although anticancer agents bearing a nitro moiety are generally considered toxic, some compounds with $\mathrm{NO}_{2}$ are currently being investigated, for example, misanidazole. ${ }^{56}$ The fact that compound $\mathbf{C 3}$ showed lower toxicity to BEAS-2B, which makes it a promising candidate for future studies.

Chrysin alongside derivatives have been studied on our selection of cell lines. Chrysin has shown $\mathrm{IC}_{50}$ higher than $200 \mu \mathrm{M}$ on leukaemia cells lines including K562 and MOLT-3; MOLT-3 and MOLT-4 are cell lines originated from the same patient with T-cell acute lymphoblastic leukaemia, having some differences in CD (cluster of differentiation) expression and chromosomal rearrangement. ${ }^{57,58}$ Samarghandian et al. ${ }^{59}$ reported $\mathrm{IC}_{50}$ values close to $20 \mu \mathrm{M}$ for breast cancer cell line MCF-7 while similar value was reported by Androutsopoulos et al. ${ }^{60}$ for MDA-MB468. On a different study, Samarghandian et al. ${ }^{61}$ reported $\mathrm{IC}_{50}$ values in the order of $40 \mu \mathrm{M}$ for chrysin on A549. Although chrysin has been tested for anticancer activity pathway elucidation on colon cancer cell models, not many have

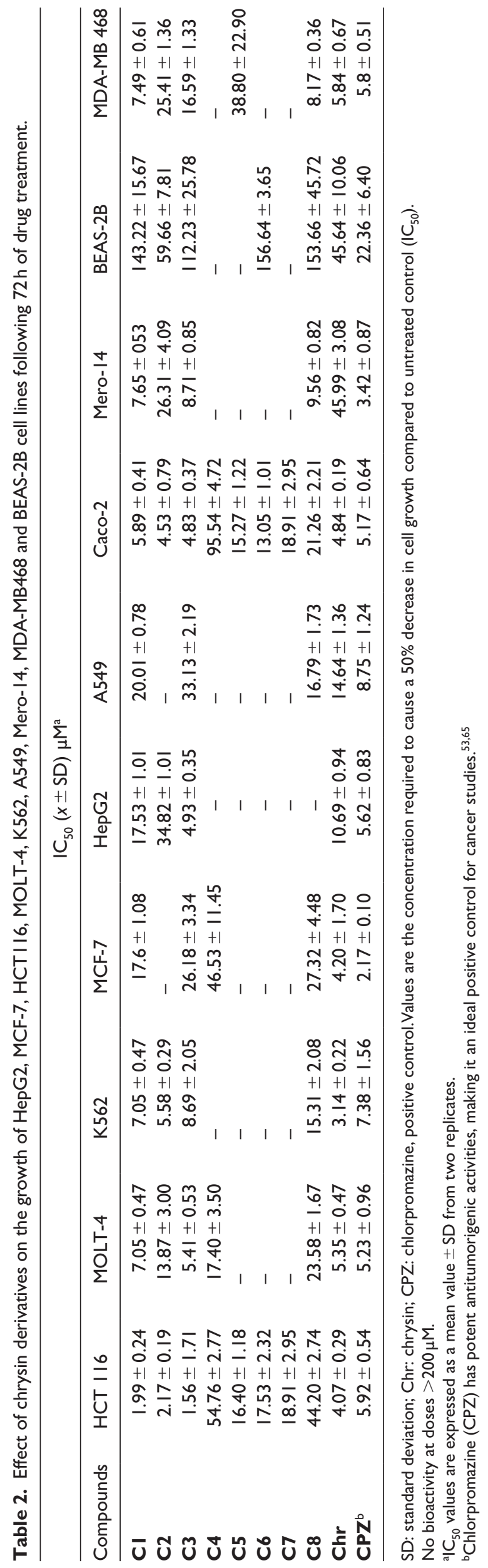


reported quantifiable values. ${ }^{62}$ A study using Chinese and Brazilian propolis reported $\mathrm{IC}_{50}$ values higher than $50 \mu \mathrm{M}$ for Caco-2 and $12-40 \mu \mathrm{M}$ for HCT116, respectively. ${ }^{63}$ Chrysin has also been investigated on hepatic model HepG2, with Zhang et al. ${ }^{64}$ reporting an $\mathrm{IC}_{50}$ value of $98 \mu \mathrm{M}$. To the best of our knowledge, no studies using flavonoids, propolis nor chrysin have been reported through the scientific literature, so we present here first ever studies of chrysin and its derivatives on this mesothelioma cell line.

\section{Lipophilicity (clogP)}

Lipophilicity has a significant impact on various drug properties including absorption, distribution and permeability. ${ }^{66}$ For a drug to reach its target, needs to penetrate the lipid bilayer of the cellular membranes, and one of the first barriers a drug encounters is situated in the enterocytes in the intestinal epithelia. In general, a rule of thumb indicates that lipophilic drugs have good absorption. ${ }^{67}$

Lipophilicity indicates partition between two immiscible phases. In the case of enterocytes, the drug needs to be absorbed through the apical side, for this being a lipophilic molecule might be helpful; but once the drug is inside, it needs to travel through the cytoplasm to be able to exit through the basolateral side of the cell. In this situation, there needs to be a delicate equilibrium between lipophilicity and lipophobicity, if the molecule is highly lipophilic, it might not be able to leave the lipid layer. One way of early detection during the drug design process is to employ the Lipinski's Rule of Five, for which the calculated $\log _{10} \mathrm{P}$ is $\leqslant 5$. ${ }^{68}$ Lipophilicity can be predicted using software, for example, ChemDraw, where a highly lipophilic drug would have a clogP $>3 .{ }^{69}$ Highly lipophilic drugs would also have solubility problems. The clogP of several molecules in the market for oral delivery present $\operatorname{cog} P$ in the ranges of -1 to 5 , with the maximum between 1.5 and $3 .^{70}$ In the case of antibacterial commercial drugs, it appears that general physicochemical properties for these compounds are outside the range of other types of pharmaceutical molecules. An in-depth analysis of marketed antibacterial molecules showed that for around $34.4 \%$ of them, their $\log P$ were in the range of $0-5 .^{71}$

Chrysin has a clogP of 2.29 and is widely known to have absorption problems, therefore affecting its bioavailability, calculated to be $0.003 \%-0.02 \%$ through the oral route of administration. ${ }^{72,73} \mathbf{C 1}$ has a clogP of 2.83, the ester group can enhance the lipid solubility of this molecule respect to chrysin, making it more available to cross the cellular barrier. $\mathbf{C 3}$ has a clogP of 4.29, and the two nitro groups capable of ionisation can enhance the solubility of this compound. In the antimicrobial panel, only $\mathbf{C 1}$ and $\mathbf{C 3}$ showed to be active; while compounds $\mathbf{C 2}$ and $\mathbf{C 4 - C 7}$ had clogP between 3.78 and 6.30, and they did not show any relevant antimicrobial activity. The halogenated compound C8 had a clogP of 4.26, but no interesting antimicrobial properties. In relation to anticancer activity, most of the compounds had clogP lower than 5 (except C2 and C5C7). $\mathbf{C} 2$ presented high anticancer activities in general but
C5-C7 were quite inactive. The $\mathrm{pKa}$ for these derivatives were also predicted using ChemDraw 20.1, and they were in the range between 5.89 and 7.02 making them more of neutral molecules. It certainly emphasises than although lipophilicity is an extremely important property, other features of the molecule are as relevant. From our group of compounds, $\mathbf{C} 3$ had a clogP $\leqslant 5$ and was the best biologically active molecule.

\section{Conclusion}

Chrysin is certainly a promising molecule for anticancer studies and can be an excellent scaffold for drug design as some derivatives offer incredible biological activities. ${ }^{50,74}$ The synthetic procedures employed to produce the chrysin derivatives were designed and optimised to produce high yields of the novel compounds utilising greener chemistry conditions. In our microbiological studies, C1 and C3 showed a remarkable increase of activity, but $\mathbf{C} \mathbf{3}$ when compared to chrysin, showed the most activity on all the strains especially ESBL E. coli, E. faecalis and S. aureus. This compound was also active on $P$. aeruginosa, MRSA, $K$. pneumoniae and the fungus $C$. albicans.

In our anticancer studies, we tested the compounds on a wide range of cancer models, like breast, hepatic, lung, leukaemia, colon cancer and malignant mesothelioma as well as non-cancerous cells. While chrysin was very active on the cancer models, it also showed toxicity to non-cancerous cells, maybe due to lack of selectivity for any target. Again, C1 and C3 were the most active compounds with lower activity on non-cancerous cells with $\mathbf{C} \mathbf{3}$ being the most promising one.

Some antibiotics have been shown to also exert anticancer activity, so during early drug design it is important to assess new chemical entities for activity on both types of targets. ${ }^{75,76}$ The identification of the lead C3 through a greener synthetic method will permit the development of new agents against bacteria and cancer.

\section{Experimental}

\section{Materials and instruments}

Unless stated otherwise all chemicals and reagents were used as received. Synthetic reagents were purchased from Sigma-Aldrich, Thermo Fisher Scientific, Apollo Scientific or TCI-UK. ${ }^{1} \mathrm{H}$ and ${ }^{13} \mathrm{C}$ NMR spectra were measured on a Bruker Avance DPX $400 \mathrm{MHz}$ spectrometer using DMSO- $\mathrm{d}_{6}$ or $\mathrm{CDCl}_{3}$ as the solvent, and tetramethylsilane (TMS; $\delta=0$ ) as the internal reference. All solvents used for NMR analysis were purchased from Cambridge Isotope Laboratories Incorporated. $J$-values are given in Hz. High-Resolution Mass Spectrometry for novel compounds were outsourced, and they were analysed using the positive electrospray ionisation time-of-flight mass spectrometry (TOF MS ES) on Waters I-Class UPLC at Cambridge Analytical Services, University of Cambridge, UK. Calculated $\mathrm{M}+\mathrm{H}$ were performed using ChemDraw 20.1 software. Infrared spectra were measured on a Thermo Scientific Nicolet iS10 and 
melting point analysis was performed on a Stuart Melting Point SMP20. Microwave-assisted reactions were performed in a CEM Discover SP microwave reactor. Silica gel chromatography was performed using silica gel $60 \AA$ with a pore size of 40-63 $\mu \mathrm{m}$ (Fluorochem Limited, Glossop, UK). Silica thin-layer chromatography was performed on precoated aluminium sheets with a $0.2-\mathrm{mm}$ thickness obtained from Thermo Fisher Scientific, UK. Anhydrous tetrahydrofuran was distilled over sodium and benzophenone prior to use. All other anhydrous solvents were purchased from Thermo Fisher Scientific.

\section{Method A, synthesis of $\mathrm{Cl}, \mathrm{C} 2$ and $\mathrm{C} 3$}

Chrysin $(0.12 \mathrm{~g}, 4.7 \mathrm{mmol})$ was added to a suspension of potassium carbonate (4.0 equiv., $0.52 \mathrm{~g}, 8.4 \mathrm{mmol}$ ) in acetone $(10.0 \mathrm{~mL}) .4$-Bromobutyl acetate $(2.0$ equiv., $184 \mu \mathrm{L}$, $9.4 \mathrm{mmol}), 1$-(bromomethyl)-3,5-dimethylbenzene $(2.00$ equiv., $0.085 \mathrm{~g}, 6.4 \mathrm{mmol}$ ) or 1-bromo-2,4-dinitrobenzene (116.6 g, $4.7 \mathrm{mmol}$ ) were added to synthesise $\mathbf{C 1}, \mathbf{C} 2$ and C3, respectively, and the resulting suspension irradiated in a microwave reactor for $10 \mathrm{~min}$ at $120^{\circ} \mathrm{C}, 900 \mathrm{~W}$ for $\mathbf{C 1}$ and $\mathbf{C 3}$ and $5 \mathrm{~min}$ at $80^{\circ} \mathrm{C}, 900 \mathrm{~W}$ for $\mathbf{C 2}$. This was rapidly cooled by means of a vapour coolant to room temperature. This was then poured into crushed ice, leading to the formation of a pale brown precipitate which was left at $4{ }^{\circ} \mathrm{C}$ for $24 \mathrm{~h}$. After $24 \mathrm{~h}$, the precipitate was filtered and washed with ice cold water, followed by petroleum ether, and eluted on silica gel using 2:1 ethyl acetate:petroleum ether, v/v. The solvent was evaporated, and the precipitate dried in an oven for $24 \mathrm{~h}$ at $50^{\circ} \mathrm{C}$ to yield the desired product.

\section{Method B, synthesis of C4}

To a solution of chrysin $(0.10 \mathrm{~g}, 0.40 \mathrm{mmol})$, potassium carbonate $(0.79 \mathrm{mmol} ; 2.0$ equiv. $)$ and tetra- $n$-butylammonium bromide ( 0.2 equiv., $0.025 \mathrm{~g}, 0.08 \mathrm{mmol})$ in dimethylformamide $(10 \mathrm{~mL})$ was added 1-bromo-2-methylpropane $(2.0$ equiv., $84 \mu \mathrm{L}, 0.99 \mathrm{mmol})$. The reaction was allowed to stir for $72 \mathrm{~h}$ at $50^{\circ} \mathrm{C}$. After $72 \mathrm{~h}$, the mixture was diluted with ice cold water, acidified with $\mathrm{HCl}(6 \mathrm{~N})$ and extracted with ethyl acetate. The organic layer was concentrated to yield a yellowish-brown solid which was chromatographed on silica gel using ethyl acetate: petroleum ether (20:80 to 100:0) as mobile phase.

\section{Method C, synthesis of C5, C6 and C7}

Potassium carbonate (2.00 equiv., $0.26 \mathrm{~g}, 4.2 \mathrm{mmol}$ ) was suspended in acetonitrile $(10.0 \mathrm{~mL})$ containing chrysin $(0.12 \mathrm{~g}, 0.47 \mathrm{mmol})$. Two equiv. of bromoalkane (1-bromooctane $(142.6 \mu \mathrm{L}, 9.4 \mathrm{mmol})$ for $\mathbf{C 5}, 1$-bromononane $(195 \mu \mathrm{L}, 9.45 \mathrm{mmol})$ for $\mathbf{C 6}$ or 1 -bromodecane $(235.3 \mu \mathrm{L}$, $9.8 \mathrm{mmol}$ ) for $\mathbf{C 7}$ ) were added to a thick-walled microwave tube and the resulting suspension irradiated vigorously in a microwave reactor at $120^{\circ} \mathrm{C}$ for $8 \mathrm{~min}$ at $900 \mathrm{~W}$. The reaction was cooled rapidly by means of an auto-installed cooler system to a temperature of about $30^{\circ} \mathrm{C}$ and poured unto crushed ice. The precipitate formed was left at $4{ }^{\circ} \mathrm{C}$ for $8-12 \mathrm{~h}$ after which the precipitate was washed with ice cold water, followed by petroleum ether and dried in an oven at $50{ }^{\circ} \mathrm{C}$ for $12 \mathrm{~h}$ to yield the pure compounds.

\section{Method D, synthesis of C8}

Potassium carbonate (4.00 equiv., $0.52 \mathrm{~g}, 8.4 \mathrm{mmol}$ ) was suspended in acetonitrile $(10.0 \mathrm{~mL})$ and stirred in a microwave tube for $30 \mathrm{~min}$. Chrysin $(0.12 \mathrm{~g}, 0.47 \mathrm{mmol})$ and 1 equiv. of 1,4-dibromopentane $(93 \mu \mathrm{L}, 4.72 \mathrm{mmol})$ were added and the resulting suspension stirred for $24 \mathrm{~h}$ at $80^{\circ} \mathrm{C}$. The resulting suspension was allowed to cool to room temperature and poured into crushed ice, leading to the formation of pale-yellow precipitate which was left at $4{ }^{\circ} \mathrm{C}$ for $24 \mathrm{~h}$. After $24 \mathrm{~h}$, the precipitate was filtered and washed with ice cold water, followed by petroleum ether, and eluted in silica gel using 2:1 ethyl acetate:petroleum ether, v/v. The solvent was evaporated, and the precipitate dried in an oven for $24 \mathrm{~h}$ at $50^{\circ} \mathrm{C}$.

4-((5-hydroxy-4-oxo-2-phenyl-4H-chromen-7-yl)oxy)butyl acetate (CI). Yield: $80 \%$; m.p. $122-124{ }^{\circ} \mathrm{C}$; clogP: 2.83. ${ }^{1} \mathrm{H}$ NMR $\left(\mathrm{CDCl}_{3}, \delta \mathrm{ppm}\right) 1.83-1.94\left(4 \mathrm{H}, \mathrm{m}, 3 "-\mathrm{H}_{2}\right.$ and $\left.4 "-\mathrm{H}_{2}\right), 2.09$ $\left(3 \mathrm{H}, \mathrm{s}, 8^{\prime \prime}-\mathrm{H}_{3}\right), 4.06\left(2 \mathrm{H}, \mathrm{t}, J=4.4 \mathrm{~Hz}, 5^{\prime \prime}-\mathrm{H}_{2}\right), 4.24(2 \mathrm{H}, \mathrm{t}$, $\left.J=5.88 \mathrm{~Hz}, 2 "-\mathrm{H}_{2}\right), 6.38(1 \mathrm{H}, \mathrm{s}, 6-\mathrm{H}), 6.51(1 \mathrm{H}, \mathrm{s}, 8-\mathrm{H})$, $6.69(1 \mathrm{H}, \mathrm{s}, 3-\mathrm{H}), 7.55$ (3H, m, 2'-H, 3'-H, 4'-H), $7.92(2 \mathrm{H}$, $\left.\mathrm{d} J=7.3,2^{\prime}-\mathrm{H}, 66^{\prime}-\mathrm{H}\right), 12.9(1 \mathrm{H}, \mathrm{s}, 5-\mathrm{OH}) .{ }^{13} \mathrm{C} \mathrm{NMR}\left(\mathrm{CDCl}_{3}\right.$, $\delta$ ppm) 20.9 (8"), 25.3 (3"), 25.6 (4"), 63.9 (5"), 67.9 (2"), 76.7-77.3 $\left.\left(\mathrm{CDCl}_{3}\right), 93.1(8), 98.5(6), 105.73\right), 105.9(4 \mathrm{a})$, $126.3\left(3^{\prime} / 5^{\prime}\right), 129.1\left(4^{\prime}\right), 131.3\left(2^{\prime} / 6^{\prime}\right), 131.8\left(1^{\prime}\right), 157.8(8 \mathrm{a})$, 162.2 (5), 163.9 (2), 164.9 (7), 171.1 (7"), 182.4 (4). IR $\left(\mathrm{cm}^{-1}\right)$ : $1165.42(\mathrm{C}-\mathrm{O}-\mathrm{C}$, large ring $\mathrm{C}-\mathrm{O}$ stretch), 1031.25, 1242.32 (C-O, phenolic), $1588.12(\mathrm{C}=\mathrm{C}$ aromatic), 1605.21 ( $\mathrm{C}=\mathrm{O}$, ketone), 1751.27 (OC=O). HRMS (ESI) m/z: calculated for $\mathrm{C}_{21} \mathrm{H}_{20} \mathrm{O}_{6}[\mathrm{M}+1]=369.1293$, found 369.1330 .

7-((3,5-dimethylbenzyl)oxy)-5-hydroxy-2-phenyl-4H-chromen-4one (C2). Yield: 52\%; m.p.: $122-124{ }^{\circ} \mathrm{C}$; clogP: 5.26. ${ }^{1} \mathrm{H}$ NMR $\left(\mathrm{CDCl}_{3}, \delta \mathrm{ppm}\right) 2.25\left(6 \mathrm{H}, \mathrm{s}, 9 "-\mathrm{H}_{3}, 10 "-\mathrm{H}_{3}\right), 4.95$ $\left(2 \mathrm{H}, \mathrm{s}, 4 "-\mathrm{H}_{2}\right), 6.34(1 \mathrm{H}, \mathrm{d}, J=2.4 \mathrm{~Hz}, 6-\mathrm{H}), 6.48(1 \mathrm{H}, \mathrm{d}$, $J=2.4 \mathrm{~Hz}, 8-\mathrm{H}), 6.57(1 \mathrm{H}, \mathrm{d}, J=2.7 \mathrm{~Hz}, 3-\mathrm{H}), 6.92(1 \mathrm{H}, \mathrm{s}$, 6"-H), 6.97 (2H, s, 2"-H, 8"-H), 7.45 (3H, m, 3'-H, 4'-H, $\left.5^{\prime}-\mathrm{H}\right), 7.80$ (2H, dd, $\left.J=7.3,2.6 \mathrm{~Hz} 2^{\prime}-\mathrm{H}, 66^{\prime}-\mathrm{H}\right), 12.80(1 \mathrm{H}$, s, 5-OH). ${ }^{13} \mathrm{C} \mathrm{NMR}\left(\mathrm{CDCl}_{3}, \delta \mathrm{ppm}\right) 23.3\left(9^{\prime \prime} / 10^{\prime \prime}\right), 70.4-77.4$ $\left(\mathrm{CDCl}_{3}\right), 93.5$ (8), 100.9 (6), 105.9 (3), 105.9 (4a), 125.3 (4"/8"), $126.3\left(3^{\prime} / 5^{\prime}\right), 129.1\left(4^{\prime}\right), 130.1\left(2^{\prime} / 6^{\prime}\right), 131.4\left(1^{\prime}\right)$, 131.4 (6"), 135.5 (5"/7"), 136.4 (3"), 157.7 (8a), 162.2 (5), 164.0 (2), 164.8 (7), 182.5 (4). IR ( $\left.\mathrm{cm}^{-1}\right): 1158.49$ (C-O-C, large ring $\mathrm{C}-\mathrm{O}$ stretch), 1246.45 (C-O, phenolic), 1583.85 $(\mathrm{C}=\mathrm{C}$ aromatic $), 1602.10(\mathrm{C}=\mathrm{O}$, ketone $), 2854.31(\mathrm{C}-\mathrm{H}$, alkane), 3001.46 (C-H, aromatic). HRMS (ESI) m/z: calculated for $\mathrm{C}_{24} \mathrm{H}_{22} \mathrm{O}_{4}[\mathrm{M}+1]=373.1395$, found 373.1433 .

7-(2,4-dinitrophenoxy)-5-hydroxy-3-phenyl-4H-chromen-4-one (C3). Yield: 46\%; m.p. 292-294 ${ }^{\circ} \mathrm{C}$; clogP: 4.29. ${ }^{1} \mathrm{H}$ NMR (DMSO-d 6 , $\delta$ ppm) $6.71(1 \mathrm{H}, \mathrm{D}, J=3.5 \mathrm{~Hz}, 6-\mathrm{H}), 7.11(1 \mathrm{H}$, d, $J=3.5 \mathrm{~Hz}, 8-\mathrm{H}), 7.19(1 \mathrm{H}, \mathrm{s}, 3-\mathrm{H}), 7.65\left(4 \mathrm{H}, \mathrm{m}, 3^{\prime}-\mathrm{H}\right.$, $\left.4^{\prime}-\mathrm{H}, 5^{\prime}-\mathrm{H}, 3^{\prime \prime}-\mathrm{H}\right), 8.12\left(2 \mathrm{H}, \mathrm{d}, J=7.0 \mathrm{~Hz}, 2^{\prime}-\mathrm{H}, 6^{\prime}-\mathrm{H}\right), 8.57$ $(1 \mathrm{H}, \mathrm{dd}, J=10.5,3.5 \mathrm{~Hz}, 4 "-\mathrm{H}),, 8.98(1 \mathrm{H}, \mathrm{d}, J=3.5 \mathrm{~Hz}$, 6"-H), 13.02 (1H, s, 5-OH). ${ }^{13} \mathrm{C}$ NMR (DMSO-d,$\delta$ ppm) 30.7-40.4 (trace cyclohexane/acetone), 93.0 (8a), 102.1 
(6), 105.3 (4a), 107.8 (3), 122.0 (6"), 122.5 (3"), 126.6 (3'/5'), $129.2\left(4^{\prime}\right), 130.2\left(2^{\prime} / 6^{\prime}\right), 132.5\left(1^{\prime}\right), 140.7$ (7"), 140.8 (5"), 152.4 (1"), 157.1 (5), 160.4 (2"), 161.2 (7), 182.5 (4). IR $\left(\mathrm{cm}^{-1}\right)$ : 1149.55 (C-O-C, large ring $\mathrm{C}-\mathrm{O}$ stretch), 1248.32 (C-O, phenolic), $1535(\mathrm{~N}=\mathrm{O}$, aromatic) 1593.47 $(\mathrm{C}=\mathrm{C}$ aromatic), $1623.80(\mathrm{C}=\mathrm{O}$, ketone $) . \mathrm{HRMS}(\mathrm{ESI}) \mathrm{m} / \mathrm{z}$ : calculated for $\mathrm{C}_{22} \mathrm{H}_{16} \mathrm{~N}_{2} \mathrm{O}_{8}[\mathrm{M}+1]=421.0627$, found 421.0661 .

5-hydroxy-7-isobutoxy-3-phenyl-4H-chromen-4-one (C4). Yield; 75\%; m.p. $143-145^{\circ} \mathrm{C}$; $\operatorname{clogP}: 3.78 .{ }^{1} \mathrm{H}$ NMR $\left(\mathrm{CDCl}_{3}, \delta \mathrm{ppm}\right) 1.03\left(6 \mathrm{H}, \mathrm{d}, J=6 \mathrm{~Hz}, 4 "-\mathrm{H}_{3}, 5 "-\mathrm{H}_{3}\right), 1.60$ (trace water), $2.12\left(1 \mathrm{H}, \mathrm{m}, 3^{\prime \prime}-\mathrm{H}\right), 3.83\left(2 \mathrm{H}, \mathrm{d}, J=6 \mathrm{~Hz}, 2^{\prime \prime}-\right.$ $\left.\mathrm{H}_{2}\right), 6.36(1 \mathrm{H}, \mathrm{s}, 6-\mathrm{H}), 6.52(1 \mathrm{H}, \mathrm{s}, 8-\mathrm{H}), 6.68(1 \mathrm{H}, \mathrm{s}, 3-\mathrm{H})$, $7.55\left(3 \mathrm{H}, \mathrm{d}, J=8.4 \mathrm{~Hz}, 3^{\prime}-\mathrm{H}, 4^{\prime}-\mathrm{H}, 5^{\prime}-\mathrm{H}\right), 7.91(2 \mathrm{H}, \mathrm{d}$, $\left.J=12 \mathrm{~Hz}, 2^{\prime}-\mathrm{H}, 66^{\prime}-\mathrm{H}\right), 12.78(1 \mathrm{H}, \mathrm{s}, 5-\mathrm{OH}) .{ }^{13} \mathrm{C}$ NMR $\left(\mathrm{CDCl}_{3}, \delta \mathrm{ppm}\right) 19.2\left(4^{\prime \prime} / 5^{\prime \prime}\right), 28.1$ (2"/3"), 74.9-77.3 $\left(\mathrm{CDCl}_{3}\right), 93.1$ (8), 98.7 (6), 105.6 (4a), 105.9 (3), 126.3 (3'/5'), $129.1\left(4^{\prime}\right), 131.4\left(2^{\prime} / 6^{\prime}\right), 131.8\left(1^{\prime}\right), 157.8(8 \mathrm{a}), 162.1$ (5), 163.9 (2), 165.3 (7), 182.5 (4). IR ( $\left.\mathrm{cm}^{-1}\right)$ : 1149.55 (C$\mathrm{O}-\mathrm{C}$, large ring $\mathrm{C}-\mathrm{O}$ stretch), $123.99 \mathrm{~cm}^{-1}$ (C-O, phenolic), $1587.00(\mathrm{C}=\mathrm{C}$ aromatic), $1614.79(\mathrm{C}=\mathrm{O}$, ketone $), 2859.02$ (C-H, alkane), $2953.21\left(\mathrm{CH}_{3}\right.$, alkane $), 3076.84(\mathrm{CH}$, aromatic). HRMS (ESI) $\mathrm{m} / \mathrm{z}$ : calculated for $\mathrm{C}_{19} \mathrm{H}_{18} \mathrm{O}_{4}$ $[\mathrm{M}+1]=311.1239$, found 311.1278 .

5-hydroxy-7-(octyloxy)-3-phenyl-4H-chromen-4-one (C5). Yield: 49.3\%; m.p. 77-80 ${ }^{\circ} \mathrm{C}$; $\operatorname{clogP}: 5.47 .{ }^{1} \mathrm{H} \mathrm{NMR}$ $\left(\mathrm{CDCl}_{3}, \delta \mathrm{ppm}\right) 0.92\left(3 \mathrm{H}, \mathrm{t}, J=7.0 \mathrm{~Hz}, 9^{\prime \prime}-\mathrm{H}_{3}\right), 1.35(8 \mathrm{H}$, $\left.\mathrm{m}, 5^{\prime \prime}-\mathrm{H}_{2}, 6 "-\mathrm{H}_{2}, 7 "-\mathrm{H}_{2}, 8 "-\mathrm{H}_{2}\right), 1.48\left(2 \mathrm{H}, \mathrm{m}, 4 "-\mathrm{H}_{2}\right), 1.49$ $\left(2 \mathrm{H}, \mathrm{m}, 4 "-\mathrm{H}_{2}\right) 1.85\left(2 \mathrm{H}\right.$, quint, $\left.J=7.0 \mathrm{~Hz}, 3 "-\mathrm{H}_{2}\right), 4.03$ $\left(2 \mathrm{H}, \mathrm{t}, J=7.2 \mathrm{~Hz}, 2 "-\mathrm{H}_{2}\right), 6.47(1 \mathrm{H}, \mathrm{d}, J=4.0 \mathrm{~Hz}, 6-\mathrm{H})$, $6.52(1 \mathrm{H}, \mathrm{d}, J=4.0 \mathrm{~Hz}, 8-\mathrm{H}), 6.68(1 \mathrm{H}, \mathrm{s}, 3-\mathrm{H}), 7.27$ $\left(\mathrm{CDCl}_{3}\right) 7.55\left(3 \mathrm{H}, \mathrm{d}, J=11 \mathrm{~Hz}, 3^{\prime}-\mathrm{H}, 4^{\prime}-\mathrm{H}, 5^{\prime}-\mathrm{H}\right), 7.91(2 \mathrm{H}$, d, $\left.J=9 \mathrm{~Hz}, 2{ }^{\prime}-\mathrm{H}, 66^{\prime}-\mathrm{H}\right), 12.9(1 \mathrm{H}, \mathrm{s}, 5-\mathrm{OH}) .{ }^{13} \mathrm{C}$ NMR $\left(\mathrm{CDCl}_{3}, \delta \mathrm{ppm}\right) 14.1$ (9"), 22.7 (8"), 25.9 (7"), 28.9 (6"), 29.2 (4"/5"), 29.3 (3"), 31.8 (2"), 68.7 (1"), 76.7-77.4 $\left(\mathrm{CDCl}_{3}\right), 93.1$ (8), 98.6 (6), 105.6 (4a), 105.8 (3), 126.2 (3'/5'), $129.1\left(4^{\prime}\right), 131.4\left(2^{\prime} / 6^{\prime \prime}\right), 131.8\left(1^{\prime}\right), 157.8(8 \mathrm{a}), 162.2$ (5), 163.9 (2), 165.2 (7), 182.5 (4). IR $\left(\mathrm{cm}^{-1}\right): 1169.51(\mathrm{C}-$ $\mathrm{O}-\mathrm{C}$, large ring $\mathrm{C}-\mathrm{O}$ stretch), 1272.96 (C-O, phenolic), $1587.89(\mathrm{C}=\mathrm{C}$ aromatic), $1607.79(\mathrm{C}=\mathrm{O}$, ketone $), 2643.39$ (C-H, alkane), 2918.76 (C-H, alkane), 3023.26 (C-H, aromatic). HRMS (ESI) m/z: calculated for $\mathrm{C}_{23} \mathrm{H}_{26} \mathrm{O}_{4}$ $[\mathrm{M}+1]=367.1865$, found 367.1899 .

5-hydroxy-7-(nonyloxy)-3-phenyl-4H-chromen-4-one (C6). Yield: 47\%; m.p. $73-76^{\circ} \mathrm{C}$; $\operatorname{clog} \mathrm{P}: 5.88 .{ }^{1} \mathrm{H}$ NMR $\left(\mathrm{CDCl}_{3}, \delta \mathrm{ppm}\right) 0.92\left(3 \mathrm{H}, \mathrm{t}, J=7.0 \mathrm{~Hz}, 10 "-\mathrm{H}_{3}\right), 1.32(10 \mathrm{H}$, $\left.\mathrm{m}, 5 "-\mathrm{H}_{2}, 6 "-\mathrm{H}_{2}, 7 "-\mathrm{H}_{2}, 8 "-\mathrm{H}_{2}, 9 "-\mathrm{H}_{2}\right), 1.48$ (2H, m, $\left.4 "-\mathrm{H}_{2}\right), 1.85\left(2 \mathrm{H}\right.$, quint, $\left.J=6.4 \mathrm{~Hz}, 3 "-\mathrm{H}_{2}\right), 4.03(2 \mathrm{H}$, t, $\left.J=7.6 \mathrm{~Hz}, 2 "-\mathrm{H}_{2}\right), 6.37(1 \mathrm{H}, \mathrm{s}, 3-\mathrm{H}), 6.50(1 \mathrm{H}, \mathrm{s}, 8-\mathrm{H})$, $6.68(1 \mathrm{H}, \mathrm{s}, 3-\mathrm{H}), 7.28\left(\mathrm{CDCl}_{3}\right) 7.55\left(3 \mathrm{H}, \mathrm{m}, 3^{\prime}-\mathrm{H}, 4^{\prime}-\mathrm{H}\right.$, 5'-H), 7.90 (2H, d, J=13 Hz, 2'-H, 6'-H), 12.71 (1H, s, 5-OH). ${ }^{13} \mathrm{C} \mathrm{NMR}\left(\mathrm{CDCl}_{3}, \delta \mathrm{ppm}\right) 14.1$ (10"), 25.7 (9"), 25.9 (8"), 28.9 (7"), 29.3 (6"), 29.3 (4"/5"), 29.5 (3"), 31.9 (2"), 68.7 (1"), 76.7-77.3 $\left(\mathrm{CDCl}_{3}\right), 93.1$ (8), 98.6 (6), $105.6(4 \mathrm{a}), 105.9(3), 126.3\left(3^{\prime} / 5^{\prime}\right), 129.1\left(4^{\prime}\right), 131.4\left(2^{\prime} / 6^{\prime}\right)$, $131.8\left(1^{\prime}\right), 157.8$ (8a), 162.1 (5), 163.9 (2), 165.2 (7), 182.5 (4). IR $\left(\mathrm{cm}^{-1}\right)$ : 1169.51 (C-O-C, large ring $\mathrm{C}-\mathrm{O}$ stretch),
1272.96 ( $\mathrm{C}-\mathrm{O}$, phenolic), $1505.20 \quad(\mathrm{C}=\mathrm{C}$ aromatic $)$, 1660.79 ( $\mathrm{C}=\mathrm{O}$, ketone), $2323.48(\mathrm{C}-\mathrm{H}$, alkane), 2643.39 (C-H, alkane), $2918.76(\mathrm{CH}$, alkane), $3018.56(\mathrm{C}-\mathrm{H}$, aromatic). HRMS (ESI) $\mathrm{m} / \mathrm{z}$ : calculated for $\mathrm{C}_{24} \mathrm{H}_{28} \mathrm{O}_{4}$ $[\mathrm{M}+1]=381.2021$, found 381.2057.

7-(decyloxy)-5-hydroxy-3-phenyl-4H-chromen-4-one (C7). Yield: 56\%; m.p. $74-76{ }^{\circ} \mathrm{C}$; clogP: $6.30 .{ }^{1} \mathrm{H}$ NMR $\left(\mathrm{CDCl}_{3}, \delta \mathrm{ppm}\right) 0.89\left(3 \mathrm{H}, \mathrm{t}, J=4.9 \mathrm{~Hz}, 11^{\prime \prime}-\mathrm{H}_{3}\right), 1.32(12 \mathrm{H}$, m, 5"- $\mathrm{H}_{2}$ 6"- $\left.\mathrm{H}_{2}, 7 "-\mathrm{H}_{2}, 8 "-\mathrm{H}_{2}, 9 "-\mathrm{H}_{2}, 10 "-\mathrm{H}_{2}\right), 1.48(2 \mathrm{H}$, m, 4"- $\left.\mathrm{H}_{2}\right), 1.85\left(2 \mathrm{H}\right.$, quint, $\left.J=7.4 \mathrm{~Hz}, 3 "-\mathrm{H}_{2}\right), 4.06(2 \mathrm{H}, \mathrm{t}$, $\left.J=7.4 \mathrm{~Hz}, 2 "-\mathrm{H}_{2}\right), 6.38(1 \mathrm{H}, \mathrm{s}, 6-\mathrm{H}), 6.52(1 \mathrm{H}, \mathrm{s}, 8-\mathrm{H})$, $6.78(1 \mathrm{H}, \mathrm{s}, 3-\mathrm{H}), 7.52$ (3H, m, 3'-H, 4'-H, 5'-H), 7.90 $\left(2 \mathrm{H}, \mathrm{d}, J=7.8 \mathrm{~Hz}, 2^{\prime}-\mathrm{H}, 6{ }^{\prime}-\mathrm{H}\right), 12.75(1 \mathrm{H}, \mathrm{s}, 5-\mathrm{OH}) .{ }^{13} \mathrm{C}$ NMR $\left(\mathrm{CDCl}_{3}, \delta\right.$ ppm) 14.1 (11"), 22.7 (10"), 25.9 (9"), 28.9 (8"), 29.3 (7"/6"), 29. 6 (4"/5"), 31.9 (3"), 68.7 (2"), 76.7-77.4 $\left(\mathrm{CDCl}_{3}\right), 93.1$ (8), 98.6 (6), 105.6 (4a), 105.9 (3), $126.3\left(3^{\prime} / 5^{\prime}\right), 129.1\left(4^{\prime}\right), 131.4\left(2^{\prime} / 6^{\prime}\right), 131.8\left(1^{\prime}\right), 157.8$ (8a), 162.1 (5), 163.9 (2), 165.2 (7), 182.5 (4). IR $\left(\mathrm{cm}^{-1}\right)$ : 1169.51 (C-O-C, large ring $\mathrm{C}-\mathrm{O}$ stretch), $1283.27(\mathrm{C}-\mathrm{O}$, phenolic $), 1512.15(\mathrm{C}=\mathrm{C}$ aromatic $), 1663.49 \quad(\mathrm{C}=\mathrm{O}$, ketone), 2286.36 (C-H, alkane), 2323.33 (C-H, alkane), 2645.76 (C-H, alkane), 3014.51 (C-H, aromatic). HRMS (ESI) $\mathrm{m} / \mathrm{z}$ : calculated for $\mathrm{C}_{25} \mathrm{H}_{30} \mathrm{O}_{4}[\mathrm{M}+1]=395.2178$, found 395.2208.

7-((4-bromopentyl)oxy)-5-hydroxy-3-phenyl-4H-chromen-4one or 7-0-2-bromopentylchrysin (C8). Yield: 94\%; m.p. 123-124 ${ }^{\circ} \mathrm{C}$; $\operatorname{clog} \mathrm{P}: 4.26 .{ }^{1} \mathrm{H}$ NMR $\left(\mathrm{CDCl}_{3}, \delta \mathrm{ppm}\right) 1.42$ (trace cyclohexane), 1.62 (trace water), $1.78(3 \mathrm{H}, \mathrm{d}$, $\left.J=9.6 \mathrm{~Hz}, 6 "-\mathrm{H}_{3}\right), 2.08\left(4 \mathrm{H}, \mathrm{m}, 3 "-\mathrm{H}_{2}, 4 "-\mathrm{H}_{2}\right), 4.08(2 \mathrm{H}, \mathrm{t}$, $\left.J=4.8 \mathrm{~Hz}, 2 "-\mathrm{H}_{2}\right), 4.22(1 \mathrm{H}, \mathrm{s}, 5 "-\mathrm{H}), 6.38(1 \mathrm{H}, \mathrm{s}, 6-\mathrm{H})$, $6.53(1 \mathrm{H}, \mathrm{s}, 8-\mathrm{H}), 6.69(1 \mathrm{H}, \mathrm{s}, 3-\mathrm{H}), 7.28\left(\mathrm{CDCl}_{3}\right), 7.55$ $\left(3 \mathrm{H}, \mathrm{m}, 3^{\prime}-\mathrm{H}, 4^{\prime}-\mathrm{H}, 5^{\prime}-\mathrm{H}\right), 7.91\left(2 \mathrm{H}, \mathrm{d}, J=8.1 \mathrm{~Hz}, 2^{\prime}-\mathrm{H}\right.$, $\left.6^{\prime}-\mathrm{H}\right), 12.80(1 \mathrm{H}, \mathrm{s}, 5-\mathrm{OH}) .{ }^{13} \mathrm{C} \mathrm{NMR}\left(\mathrm{CDCl}_{3}, \delta \mathrm{ppm}\right) 26.6$ (6"), 27.4 (3"), 37.3 (4"), 50.7 (5"), 67.7 (2"), 76.8-79.4 $\left(\mathrm{CDCl}_{3}\right), 93.9$ (8), 98.6 (6), 105.7 (4a), 108.9 (3), 126.3 (3'/5'), $130.1\left(4^{\prime}\right), 131.1\left(2^{\prime} / 6^{\prime}\right), 131.8\left(1^{\prime}\right), 157.6(8 \mathrm{a}), 162.2$ (5), 163.8 (2), 164.9 (7), 182.5 (4). IR $\left(\mathrm{cm}^{-1}\right): 765.53$ (C$\mathrm{Br}), 1172.08 \mathrm{~cm}^{-1}$ (C-O-C, large ring $\mathrm{C}-\mathrm{O}$ stretch), 1101.61 and $1270.95 \mathrm{~cm}^{-1}$ (C-O, phenolic), $1603.28 \mathrm{~cm}^{-1}$ ( $\mathrm{C}=\mathrm{C}$ aromatic $), 1621.23 \mathrm{~cm}^{-1}(\mathrm{C}=\mathrm{O}$, ketone $), 2854.31 \mathrm{~cm}^{-1}$ (C-H, alkane), $2943.23 \mathrm{~cm}^{-1}\left(\mathrm{C}-\mathrm{H}\right.$, alkane), $2965.54 \mathrm{~cm}^{-1}$ (C-H, alkane), $3068.12 \mathrm{~cm}^{-1}(\mathrm{C}-\mathrm{H}$, aromatic). HRMS (ESI) $\mathrm{m} / \mathrm{z}$ : calculated for $\mathrm{C}_{20} \mathrm{H}_{19} \mathrm{BrO}_{4}[\mathrm{M}+1]=405.0534$, found 405.0521 .

\section{Cell culture and growth inhibition studies}

DMEM supplemented with $10 \%$ heat inactivated FBS, L-glutamine $(1.0 \mathrm{mM})$ and streptomycin $(1.0 \mathrm{mM})$ was used to culture MCF-7 and Mero-14 cell lines. DMEM supplemented with $20 \%$ heat inactivated FBS, L-glutamine $(1.0 \mathrm{mM})$ and streptomycin $(1.0 \mathrm{mM})$ was used to culture Caco-2 cell line. RPMI-1640 supplemented with 10\% heat inactivated FBS, L-glutamine $(1.0 \mathrm{mM})$ and streptomycin $(1.0 \mathrm{mM})$ was used to culture K652, HepG2, MDA-MB 468, A549 and MOLT-4 cell lines. McCoys 5A supplemented with $10 \%$ heat inactivated FBS, L-glutamine $(1.0 \mathrm{mM})$ and streptomycin $(1.0 \mathrm{mM})$ was used to culture 
the HCT-116 cell line. Bronchial Epithelial Basal Medium (BEBM) from Lonza was used to culture the HCT-116 cell line. Culture was undertaken in a humidified incubator with $5 \% \mathrm{CO}_{2}$ at $37^{\circ} \mathrm{C}$ until $75 \%$ confluence was reached. The general method undertaken for growth inhibition studies used cells grown in T-75 cell culture flasks before being aliquoted into sterile 96-well plates and incubated for $12 \mathrm{~h}$. The cells were then treated with a concentration gradient $(200$ $0 \mu \mathrm{M})$ of compounds for $72 \mathrm{~h}$. Following this, the cells were aspirated and $30.0 \mu \mathrm{L}$ of 3-(4,5-dimethylthiazol-2-yl)2,5-diphenyltetrazolium bromide (MTT) $\left(5.0 \mathrm{mg} \mathrm{mL}^{-1}\right.$ in PBS) were added. The plate was incubated for $3.5 \mathrm{~h}$ at $37^{\circ} \mathrm{C}$ in an environment of $5 \% \mathrm{CO}_{2}$ before the wells were aspirated and $100 \mu \mathrm{L}$ of DMSO added. The 96-well plates were agitated using an orbital stirrer for $60 \mathrm{~s}$ before absorbance readings at 570 and $630 \mathrm{~nm}$ were taken using a Thermo Labsystems MultiSkan Ascent system. For suspension cell lines, the same method was undertaken; however, MTS was used in place of MTT, following the manufacturer's guidelines (Promega, UK). The growth inhibition studies using MTT/MTS assays were performed on a Thermo Labsystems MultiSkan Ascent system.

\section{Bacterial and fungal growth and growth inhibition studies}

Nutrient agar (agar, $15 \mathrm{gL}^{-1}$, meat extract, $1 \mathrm{gL}^{-1}$, peptone, $5 \mathrm{gL}^{-1}$, sodium chloride, $5 \mathrm{gL}^{-1}$, yeast extract, $2 \mathrm{gL}^{-1}$ ) was used to culture Bacillus cereus ATCC 10876, S. aureus ATCC 25923, Enterococcus faecalis NCIMB 13280, P. aeruginosa NCTC 13437, P. fluorescens ATCC 13525, Extended Spectrum Beta-Lactamase (ESBL) producing E. Coli NCTC 13353, MRSA 252 and K. pneumoniae ATCC 13439, and Sabouraud Dextrose Agar (SDA) was used to culture C. albicans MTCC227. Strains were cultured overnight (22-25 h) at $37^{\circ} \mathrm{C}$ on nutrient broth for the preparation of cell suspensions. Suspensions of bacterial cells (dissolved in PBS) were homogenised such that the spectrophotometry standard of $5 \times 10^{5} \mathrm{CFU} \mathrm{mL}^{-1}(0.5 \mathrm{McF}$ arland standards $)$ was obtained.

\section{Minimum inhibitory concentration studies}

MIC is considered the concentration of sample that prevents a colour change of the media and inhibited bacterial growth completely. All samples were dissolved in Mueller Hinton Broth (MHB)/DMSO with a DMSO final concentration of $2.5 \%$. The resulting solution was added to MHB. Inoculum prepared in appropriate broth - MHB $(100 \mu \mathrm{L})$ was then added. These plates were sealed and agitated using a plate shaker incubated for $18 \mathrm{~h}$ at $37^{\circ} \mathrm{C}$. A negative control (wells containing broth, DMSO and $100 \mu \mathrm{L}$ of inoculum) was also prepared. Gentamicin was used as the reference antibiotic for the bacterial strains while fluconazole was the antifungal agents tested on $C$. albicans. The $p$-iodonitrotetrazolium chloride (INT) colorimetric assay was used to determine MIC. The assay measures the production of NADH. In order to determine $\mathrm{MIC}, 40 \mu \mathrm{L}$ of $0.2 \mathrm{mg} \mathrm{mL}^{-1}$ of INT were added after incubation for $18 \mathrm{~h}$ at $37^{\circ} \mathrm{C}$ and samples were screened for colour change from violet to red.

\section{cLogP calculation}

Calculated $\log \mathrm{P}$ values were predicted using ChemDraw 20.1 .

\section{Acknowledgements}

The authors thank the technical staff at the University of Salford and Salford Analytical Services, in particular Mr Kirit Amin for his outstanding analytical contributions. The authors also express their gratitude to Dr Nanda Puspita for her outstanding help with cell culture.

\section{Declaration of conflicting interests}

The author(s) declared no potential conflicts of interest with respect to the research, authorship and/or publication of this article.

\section{Funding}

The author(s) disclosed receipt of the following financial support for the research, authorship and/or publication of this article: This study was supported by the Nigerian Government and the University of Salford.

\section{ORCID iDs}

John Hadfield (iD https://orcid.org/0000-0001-7984-8319

Patricia Ragazzon (iD) https://orcid.org/0000-0003-0374-4569

\section{Supplemental material}

Supplemental material for this article is available online.

\section{References}

1. Hemmerlin A, Harwood JL and Bach TJ. Prog Lipid Res 2012; 51: 95-148.

2. Falcone Ferreyra ML, Rius SP and Casati P. Front Plant Sci 2012; 3: 222

3. Babii C, Bahrin LG, Neagu AE, et al. J Appl Microbiol 2016; 120: 630-637.

4. van de Velde ME, Kaspers GL, Abbink FCH, et al. Crit Rev Oncol Hematol 2017; 114: 114-130.

5. Xuan HZ, Zhang JH, Wang, et al. Bioorg Med Chem Lett 2016; 26: 570-574.

6. Mani R and Natesan V. Phytochemistry 2018; 145: 187-196.

7. Kedika B, Thotla K, Noole V, et al. J Chem Pharm Res 2016; 8: 1210-1222.

8. Li BW, Zhang FH, Serrao E, et al. Bioorg Med Chem 2014; 22: 3146-3158.

9. Khan MS, Devaraj H and Devaraj N. Toxicol Appl Pharmacol 2011; 251: 85-94.

10. Zeinali M, Rezaee SA and Hosseinzadeh H. Biomed Pharmacother 2017; 92: 481-489.

11. Peng SM, Zou XQ, Ding HL, et al. Bioorg Med Chem Lett 2009; 19: 1264-1266.

12. Yixi X, Weijie Y, Fen T, et al. Curr Med Chem 2015; 22: 132-149.

13. Mani R and Natesan V. Phytochemistry 2018; 145: 187-196.

14. Farhadi F, Khameneh B and Iranshahi I. Phytotherapy Res 2018; 33: 13-40.

15. Babu KS, Babu TH and Srinivas PV. Bioorg Med Chem Lett 2006; 16: 221-224.

16. Khachatryan DS and Matevosyan KR. Russian Chem Bull 2016; 65: 14-28. 
17. Mayer S, Keglevich P, Abranyi-Balogh P, et al. Molecules 2020; 25: 888 .

18. McGown A, Ragazzon-Smith A, Hadfield JA, et al. Lett Org Chem 2019; 16: 66-75.

19. Ragazzon PA, Bradshaw T, Matthews C, et al. Anticancer Res 2009; 29: 2273-2283.

20. Almelah E, Smith DPT, McGown A, et al. Anticancer Res 2016; 36: 6043-6050.

21. Moreira J, Ribeiro D and Silva PMA. Molecules 2019; 241: 129.

22. van Acker SABE, de Groot MJ, van den Berg DJ, et al. Chem Res Toxicol 1996; 9: 1305-1312.

23. Kasprzak MM, Erxleben A and Ochocki. RSC Adv 2015; 5: 45853-45877.

24. Panda AK. Asian J Chem 2009; 21: 4856-4860.

25. Lepore SD and He TJ. Org Chem 2003; 68: 8261-8263.

26. Koussini R and Al-Shihria AS. Jordan J Chem 2008; 3: 103-107.

27. Lu Y, Liu Y, Xu Z, et al. Expert Opin Drug Dis 2012; 7: 375-383.

28. Baumann M and Baxendale IR. J Org Chem 2013; 9: 22652319.

29. Lei L, Rehman MU, Huang S, et al. Acta Trop 2018; 182: 111-114.

30. Suardana W, Widiasih DA, Ngurah G, et al. Asian Pac J Trop Biomed 2015; 5: 915-920.

31. Ben-Ami R, Rodriguez-Bano J, Arslan H, et al. Clin Infect Dis 2009; 49: 682-690.

32. Fine MJ, Smith MA, Carson CA, et al. JAMA 1996; 275: 134-141.

33. Gholizadeh $\mathrm{P}$, Maftoon $\mathrm{H}$, Aghazadeh M, et al. Rev Med Microbiol 2017; 28: 97-103.

34. Skariyachan S, Sridhar VS, Packirisamy S, et al. Folia Microbiol 2018; 63: 413-432.

35. Gershman MD, Kennedy DJ, Noble-Wang J, et al. Clin Infect Dis 2008; 47: 1372-1379.

36. Fuller AT, Mellows G, Woolford M, et al. Nature 1971; 234: 416-417.

37. Arnold RS, Thom KA, Sharma S, et al. Southern Med J 2011; 104: 40-45.

38. Xu Z, Li, Shirtliff ME, et al. Clin Microbiol Infect 2011; 17: 714-718

39. Cole AM, Tahk S, Oren A, et al. Clin Diagn Lab Immunol 2001; 8: 1064-1069.

40. Kluytmans J, van Belkum A and Verbrugh H. Clin Microbiol Rev 1997; 10: 505-520.

41. Paterson DL and Bonomo RA. Clin Microb Rev 2005; 18 : 657-686.

42. Kilbas I and Ciftci IH. J Global Antimicrob Res 2018; 12 : 26-30.

43. Mayer FL, Wilson D and Hube B. Virulence 2013; 4: 119-128.

44. Wilson D. Trends Microbiol 2019; 27: 188-189.

45. Nepali K, Lee HY and Liou JP. J Med Chem 2019; 62: 28512893.

46. Li HQ, Shi L, Li QS, et al. Bioorg Med Chem 2009; 17 : 6264-6269.
47. Li HX, Wang ZC, Qian YM, et al. Chem Biol Drug Des 2017; 89: 136-140.

48. Alhadrami HA, Hamed AA, Hassan HM, et al. Antibotics 2020; 9: 562 .

49. Petruzzi L, Corbo MR, Campaniello D, et al. Foods 2020; 9: 559.

50. Zhu Y, Yao X and Long J. Nat Prod Commun 2019; 14: $1-11$.

51. Kowalska-Krochmal B and Dudek-Wicher R. Pathogens 2021; 10: 165.

52. Sueke H, Kaye S, Neal T, et al. Invest Ophthalmol Vis Sci 2010; 51: 2519-2524.

53. Dagi HT, Findik D, Senkeles C, et al. Ann Clin Microb Antimicrob 2016; 15: 36.

54. Versnel VA, Hoogsteden HC and Hagemeijer A. Cancer Genet Cytogen 1989; 42: 115-128.

55. Park YH, Kim D, Da J, et al. Toxicol Appl Pharmacol 2015; 287: 240-245.

56. Wardman P. BJR 2018; 92: 1093.

57. Mahbub AA, Le Maitre C, Haywood-Small S, et al. Anticancer Agents Med Chem 2013; 13: 1601-1613.

58. Greenberg JM, Gonzalez-Sarmiento R, Arthur DC, et al. Blood 1988; 72: 1755-1760.

59. Samarghandian S, Azimi-Nezhad M, Borji A, et al. Pharmacogn Mag 2016; 12: S436-S440.

60. Androutsopoulos VP, Rupareli K, Arroo RRJ, et al. Toxicology 2009; 264: 162-170.

61. Samarghandian S, Nezhad MA and Mohammadi G. Anticancer Agents Med Chem 2014; 14: 901-909.

62. Choi JK, Jang YH, Lee S, et al. Food Chem Toxicol 2017; 110: 142-150.

63. Ishihara M, Noai K, Hashita M, et al. Oncol Rep 2009; 22: 349-354.

64. Zhang Q, Ma S, Liu B, et al. Exp Ther Med 2016; 12: 469474.

65. Kamgar-Dayhoff P and Brelidze TI. Oncotarget 2021; 12: $1406-1426$.

66. Liu Z, Wang S and Hu M. Pharm Theory Pract 2009; 263: 265-288.

67. Benet LZ, Hosey CM, Ursu O, et al. Adv Drug Deliv Rev 2016; 101: 89-89.

68. Effinger A, O'Driscoll CM, McAllister M, et al. J Pharm Pharmacol 2018; 71: 674-698.

69. Dalafave DS. Biomed Eng Comput Biol 2010.

70. Pajouhesh H and Lenz GR. NeuroRx 2005; 2: 541-553.

71. Ebejer JP, Charlton MH and Finn PW. J Cheminform 2016; 8: 30 .

72. Jung J. Nanoscale Biol Mat 2016; 2016: 2894089.

73. Walle T, Otake Y, Brubaker JA, et al. Br J Clin Pharmacol 2001; 51: 143-146.

74. Talebi M, Talebi M, Farkhondeh T, et al. Cancer Cell Int 2021; 21: 214.

75. Saeidnia S. New approaches to natural anticancer drugs (Springer briefs in pharmaceutical science \& drug development). Cham: Springer, 2015, pp. 51-66.

76. Lindahl LM, Wilerslev-Olsen A and Gjerdrum LMR. Blood 2019; 134: 1072-1083. 